\title{
Seventh and Eighth Grades
}

\section{Katharine M. Stilwell}

Nature Study: I. Respiration: It was found advisable to teach the children something of the mechanics of respiration before taking up the subject of ventilation; so this outline should properly have come in the December number. Let the children observe the reactions of the constituents of normal air in simple laboratory experiments.

Note what happens when lighted sulphur, phosphorus, the glowing end of a match, or a red-hot bit of iron or steel spring is thrust into a jar of oxygen.

Make nitrogen before the children by burning phosphorus in a jar of air inverted over a basin of water. Perform the same experiments as with the oxygen, and have the children note results, and tell whether nitrogen or oxygen is probably the more important element to human beings. Give them the proportions of normal air: $\mathrm{N} 79 \%, \mathrm{O} 20 \%, \mathrm{CO}_{2} .04 \%$, and teach them the meaning of the chemical symbols.

II. Organs of Respiration: (Use pictures, diagrams, and apparatus as far as possible.) Mouth, nose, throat, bronchial tubes, lungs, pleura, diaphragm, ribs, and respiratory muscles. (Avoid the multiplication of scientific terms; the object is to make the child understand how we breathe.)

III. Mechanics of Respiration. I. The dilation of the thorax (best demonstrated by use of a skeleton) as shown by: (a) The double sloping of the ribs, so that when they are lifted in front and rotated in their sockets the chest cavity is increased in size. (b) The depression of the domeshaped diaphragm into a cone-shaped membrane, and the consequent increase of the chest cavity at its biggest end.

2. How the lifting of the lateral walls of the chest increases the volume of the thorax may be shown diagrammatically by
Nott William Flint

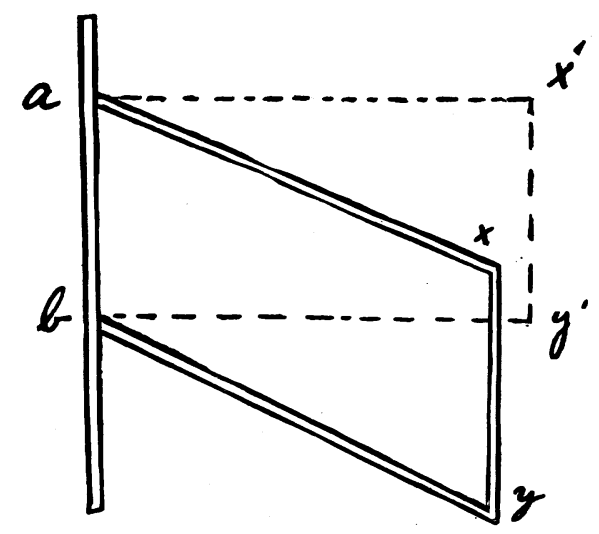

the use of a simple piece of apparatus which any child can make.

The parallelogram frame $a x b y$ is made of any convenient size, with the joints slightly loose, so that it can be moved upon the backbone $a b$. Let $a b$ represent the backbone, $a x$ and $a y$ the ribs, and $x y$ the sternum. Then $a x b y$ would be the normal position and $a x^{\prime} b y^{\prime}$ the ribs in the extended or inflated position. Compare the areas of the two figures. Which is larger?

3. Let the children hold their hands to their sides, take a deep breath, and then tell whether there is any other than an upward movement to the ribs. The mechanism of the lateral extension should be shown on a skeleton if possible. Abnormal forms of respiration and their uses: coughing, sneezing, snoring, crying, sighing, and laughing.

Number Work: (The examples are suggestive.) I. It appears that the body takes up in respiration $4.782 \%$ of $\mathrm{O}$ from the air inhaled, and gives off (about) $4.38 \%$ of $\mathrm{CO}_{2}$. What is the ratio of $\mathrm{CO}_{2}$ expired to $\mathrm{O}$ absorbed?

2. If a person breathes 30 cubic inches of air per inspiration and makes 25 inspirations a minute, how long will it take him to breathe all the air in a room 20xioxio feet? How long will it take I5? How long will it take this class to breathe the air in the room? 
3. Air containing . $40 \% \mathrm{CO}_{3}$ is bad for breathing. How long will it take to spoil the air in this room if the doors and windows are shut tight? (Factors: the number of persons; the average number of inspirations, and the per cent $\mathrm{CO}_{2}$ given off by one person.)

4. If the air is rendered injurious when $.2 \%$ of $\mathrm{CO}_{2}$ is present, how many cubic inches of air do you render impure by each respiration?

5. How many cubic feet do you render impure per hour?

References: Any good physiology; Jackman's Nature Study.

Geography: (In correlation with history.) I. The Central Highlands: North of the Danube from the Carpathians to the Rhine. Note the sweeping curve of the Alps from the Gulf of Lyons to the neighborhood of Vienna. This central ridge will make a good starting-point for the teaching, for as the birthplace of Europe's mightiest rivers, as the natural barrier between her mightiest peoples, a prime factor in the distribution of its climates, and in modern times the noblest of all international playgrounds, the Alps play a large part in the economy of the continent.

Surface: Suppose the class to be standing upon some lofty peals of the northern Alps, and to look northward. What would the country look like? What would they see?

Irregular lines and groupings of hills rising from a central table-land intersected by deepcut valleys of rivers. I. Central knot, Fichtelgebirge. 2. Eastward, Erzgebirge and the Bohemian forests. 3. Farther east, Sudettes. 4. Westward, Thuringian forests and Franconian Jura, and south of these the Suabian Jura, which joins on the Black Sea. (Class will mold these highlands in sand; they should read as much as possible on this part of Europe, and see all kinds of pictures of the country and the people.)

I. Rivers: Weser, Rhine, Elbe, Main and Neckar. With the relief map before them the class should reason out the comparative age of the rivers and the highlands.

II. The Northern Plain: Surface; formation. Coastal prain of the North Sea. Rivers.

III. Climate as dependent upon: I. Nearness to sea. 2. Direction of prevailing wind.
3. Elevation. 4. Latitude. After studying these conditions the students will be led to infer the climate of this region.

IV. The political divisions of to-day: I. Boundaries; shape; size, 212,000 square miles.

2. Commercial position: Chief exports and imports. Relation of these to the industries and manufactures. Upon what does the chief industry depend? Who is the chief customer?

3. The people: Social condition. The Agrarian, the Socialist, and the Imperial parties. Population, 50,000,000. What is the average density.

4. Internal improvements:

(a) Railways, 29,600 miles. (b) Telegraphs, 57,000. (c) Canals, 15,000. (d) Macadamized roads, 70,000 .

5. Government: Colonial possessions Africa. Islands of the Pacific. Extent, I,020,680 square miles. Population, I0,650,000. What is average density. Why do Germans emigrate to America.

\section{The Netherlands.}

I. Position: Holland is one-fifth below the level of the sea. Area of subsidence for the most part is nothing more than the delta of the Rhine.

II. Commerce: Imports, $\$ 602,500,000$. Exports, $\$ 490,000,000$. Most important are the products of agriculture and stock-raising. Means of transportation, 9,500 miles of roads and dykes; 7,000 miles of tramways (mostly steam); 2,000 miles of railways.

III. Colonies: Java, 52,554 square miles. Dutch East Indies, 685,846 square miles. Dutch West Indies, 403 square miles. Dutch Guiana, 46,060 square miles. How do its position, its commerce, and its colonies affect the importance of the Netherlands?

III. Surface: (Show pictures of Holland.) Mold Netherlands in sand. How was this land made? What part has man played in its history?

IV. Rivers and canals.

V. Area: 12,728 square miles - 26\% agricultural, 35\% grazing, $7 \%$ forest, $20 \%$ waste. Find number of square miles of each.

VI. From latitude and position with regard to North Sea and the elevation let the children determine what the climate is.

VII. The people: Occupations. Government.

III. DENMARK.

I. Surface: West and north, moorland. Southeast and in the islands, hilly. 
II. Area: I4,I24 square miles. Area of peninsula, 9,752 square miles. The Faroes. Coast of Greenland. Iceland. West Indies-St. Thomas, St. John, St. Croix. (United States is trying to buy the Danish West Indies now. Why?)

III. Coast-line: 5,000 miles. What is the number of miles of coast-line to each square mile of area?

IV. Occupations of people: One-fourth are in agriculture. Crops - rye, wheat, oats, and barley. Manufactures: Porcelain.

V. People: 2,000,000. Government.

IV. Russia.

I. Size and shape: Area, 2,090,000 square miles; length, 2,400 miles; width, I,800 miles.

II. Commercial position: What is Russia's place in the commerce of the world? Ports.

III. Surface: A vast plain; tundras. North Russian lowlands. North Russian table-lands. Steppes. Caspian depression.

IV. Drainage: I. North: Petchora, Dwina. 2. Baltic: Neva, Dura, Niemen,Vistula. 3. Black: Dniester, Dnieper, Don. 4. Caspian: Volga, Ural. Volga has 200 mouths in its delta, and is 2,230 miles long. Character of rivers.

V. Lakes.

VI. Climate: Plain open to north and south. (Effect of this?)

VII. Black lands: Between Carpathians and Urals, 240,000,000 acres.

VIII. Industries: I. Agriculture: Wheat, maize, oats, and rye. 2. Fisheries and grazing.

IX. Commerce.

$X$. Waterways and landways: 24,000 miles of navigable rivers; Trans-Siberian railroad.

XI. People: 88,000,000. Government; compare with that of United States. Readings from Gogol's Taras Bulba and from Tolstoi's Resurrection.

References: Ballou, Footprints of Travel; Chisholm, Handbook of Commercial Geography; Reclus, Bird's-eye View of the World; Ibid, Earth and Its Inhabitants; Mill, International Geography; James Sime, Geography of Europe; Henty, Lion of the North (illustrative of the Thirty Years' War); F. W. Longman, Frederick the Great and the Seven Years' War; Yonge, Young Folks' History of Germany; Motley, Rise of the Dutch Republic; Wallace, Russia.

Number work: (Correlated with geography.) I. The Haarlem engineers at a cost of $\$ 765,000$ recovered from the sea an area of 15,000 acres. What did the work cost per acre?
2. The Volga from its source to its mouth is I,005 miles as the crow flies; its actual length is 2,130 . What is its average length per mile of distance?

3. The basin area of the Danube is 299,435 square miles. What per cent of the continent of Europe is this?

4. Europe has an area of $3,823,383$ square miles. If the material of which the Alps are composed were spread equally over the surface of the continent the level would be raised 89 feet. How much material is there in the Alps? What is the average size of the eighteen countries of Europe?

5. Germany has an area of $133,695,000$ acres, a population of about 50,000,000, and a forest area of $13,924,000$ acres. How much arable land is there per person? What per cent of the land is covered by forest?

6. In 1787 there was said to be $144,000,000$ people in Europe, and in $1874,309,178,000$. What was the average annual increase? At the same rate what would the population be now?

History: (Teutonic Migrations.) I. Locate the Teutons at home in the forests of Germany.

Have the children observe pictures of the country from geographical books and from the school picture collection. Infer the character of people in such an environment.

II. Read from the Germania of Tacitus a description of the Teutons.

III. Have the children place themselves in a similar environment, and reason out what their life would be. Take up the following points:

I. The village community.

2. The houses; the common land.

3. Appearance of the people; their dress; their arms.

4. The occupations; implements. Use pictures and sketches by the teacher to illustrate the above. Visit the museums.

5. The government: The village assembly; the growth of representation. Criminal law; "eye for eye"; the blood-wite; compensation by family. Class will read Chapter I in Green's Short History of the English People.

6. Classes of society: (a) chief; (b) nobles by birth, earls; (c) freemen, céorls; (d) slaves, prisoners of war or criminals.

IV. Rise of kingship.

The pupils will reason out the steps between the choosing of a strong man for leadership in war and the development of the kingship. 
Read from Guizot's History of France the story of the Vase of Soissons.

V. Their contact with Rome.

Read Kingsley's myth of the Troll-garden, from The Roman and the Teuton. Recall the barbarian encounter with (I) Marius; (2) Cæsar; and discuss what the Teutons gained from Rome.

VI. Compare the Teutonic and the Roman principles of government.

VII. The Teutonic movements. The causes. Trace routes over Europe. From relief maps the class will judge what routes would be chosen.

VIII. The invasion of England.

References: Tacitus, Germania; Green, History of the English People; Kingsley, The Roman and the Teuton; Guizot, History of Civilization; Emerton, History of the Middle Ages.

French: Since Mlle.Ashléman is attempting to correlate French closely with other subjects, there will be no outline for this month-the work is too experimental to be forecast. Next month, however, Mlle. Ashléman will publish a report of her experiments in correlation.

Art: In connection with the history, the class will paint and draw pictures of some of the stirring scenes and events which occurred in the Gothic invasions of the Roman Empire.

Speech, Oral Reading, and Dramatic Art: We shall continue the study of Julius Cæsar begun in January. The relation of this draina to the history of Rome, in which the children are interested, need not be discussed, since it is in the spirit and atmosphere of the times. They read the play first for the story, just as we do, reading it many, many times. No attempt was made to get at the meaning of difficult words, phrases, or constructions. They told the story in as short a time as possible, speaking always to the whole school. Then followed discussions as to what were the essential parts of the story. The result was the story in its simplest form. When the children had written the story, they passed easily to a synopsis of the play. The study of character began unconsciously with the first readings. The children know the people in the play and the conditions under which they are acting. They are real men and women, real human beings. The class has learned to make comparisons, to draw inferences, to search for the motive of action, proving each statement or opinion by the text. They have learned to weigh the words of Brutus and the other men-when Brutus speaks alone in soliloquy and when he speaks to or of others. They judge in a measure by the public opinion-what other men say of him-and his own deliberate and impulsive acts.

By this study the greater part of the play has been read orally and the construction of the play is familiar to the children. In February, or as soon as they are ready for it, we shall prepare for dramatic presentation some of the great scenes, beginning with the first scene of the first act as an introduction, and passing on to the second scene.

Music: There is very little material for correlation in the subject-matter of the songs for these grades, and it is of far less importance here than in lower grades. This is partly because the children have already fixed habits of self-consciousness which make reference in an emotional form to what are to them the commonplaces of their lives seem forced and artificial. The chief reason, however, is that singing is above all a highly spiritual form of expression and tends naturally to get further and further away in its subject-matter from the concrete, and nearer the spiritual.

Songs of general import, ethical songs, and hymns are found most practicable for these children, and less attention is paid to expression of feeling than to simple matters of technique which tend to make the declamation of the song intelligent and in- 
telligible. These are chiefly distinctions of enunciation and the taking of the breath in places which help.to make the sense of the text clear.

A few of the boys have been excused from singing altogether on account of the change of voice. The children chosen for alto parts are not merely the musical ones who can do it easily, but those having alto voices, and those whose upper tones are in poor (not merely undeveloped) condition. A short review of Tyrolese and Highland songs and some Norwegian mountain-songs will be made in connection with the geography work. This will consist in listening to the songs played or sung for them and discovering their salient characteristics.

Songs: Flag Song; Fatherland's Psalm, February Course of StUdy; Hail, Columbia, Modern Music Series, Second and Third Books; The Hardy Norseman, Modern Music Series, Third Book; Morning and Night, The King of Love, Songs of Life and Nature.

\section{Algebra for the Seventh and Eighth Grades. George W. Myers.}

62. If $A$ denote the amount, $P$ the principal, $t$ the time in years, and $r$ the rate, write an equation for $A$.

63. By dividing and transforming the latter equation, derive all the cases of simple interest.

64 . Let $P$ represent the principal, or the annual rate, $t$ the number of years, $I$ the compound interest, $A$ the compound amount, and $a$ the compound amount on one dollar. What is the amount for one year? For two years? For three years? For four years? Whence for $t$ years it is $P a^{\mathrm{t}}$, or $A=P a^{\mathrm{l}}=P(\mathrm{I}+r)^{\mathrm{t}}$. Here give problems to show the efficiency of these equations.

Note. - The interest is supposed to be payable annually. What would the above equations become if the interest were payable quarterly?

Multiply 17 by 23 and notice carefully what operations you perform. You say 3 times 7 equals $2 \mathrm{I}$; then 3 times $\mathrm{I}$ ten equals 30 units; then 7 times 2 tens equals I 40 units, and finally, 2 tens by I ten equals 200 units; then you add all these products, thus: $21+30+140+200=391$.
These operations arè more obvious by proceeding thus:

$$
\begin{aligned}
& 17=10+7 \\
& 23=20+3
\end{aligned}
$$

The products are then formed by multiplying both parts of 17 by 3 , and then both parts by 20 . These four partial products are then added to obtain the product of 17 by 23 .

The problem might also have been solved thus:

$$
\begin{aligned}
& 17=20-3 \\
& 23=30--7
\end{aligned}
$$

Here we should first multiply 3 by 7 , then 20 by 7 , and subtract the former product from the latter. Then we should multiply 3 by 30 and 20 by 30 , and again subtract the former from the latter. Finally we should subtract the first difference from the second, whence we should obtain the same result as before, viz:, 39I.

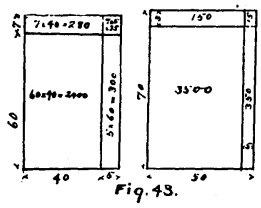

65. Apply both of these methods to $67 \times 45$, writing the problem first, $(60+7) \times(40+5)$, and second, $(70-3) \times(50-5)$, and compare the partial products in the first case with the parts of the first oblong and those of the second case with the parts of the second oblong in the cut.

66. Apply both methods to $54 \times 36$ and illustrate by diagrams as in 65 .

67. Apply these methods to $56 \times 96$ and illustrate them by diagrams.

Note. - We see thus that $78 \times 6_{3}=(70+8) \times$ $(60+3)=70 \times 60+70 \times 3+8 \times 60+8 \times 3=4914$, or that $78 \times 63=(80-2) \times(70-7)=80 \times 70-80 \times 3$ $-2 \times 70+2 \times 3=4914$.

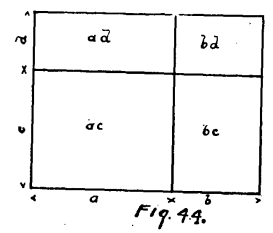

68. Show by referring to the diagram that $(a+b) \times(c+d)=a c+a d+b c+b d$.

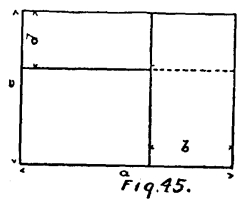

69. Show in the same way that $(a-b) \times$ $(c--d)=a c-a d-b c+b d$. 


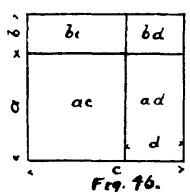

70. Draw a diagram and show by its aid that $(a+b) \times(c-d)=a c+b c-a d-b d$.

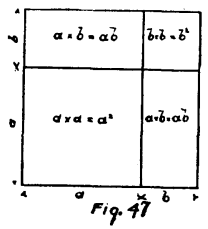

71. Referring to the adjoining figure, show that $(a+b) \times(a+b)=a^{2}+a b+a b+b^{2}$, or more briefly, $(a+b)^{2}=a^{2}+2 a b+b^{2}$.

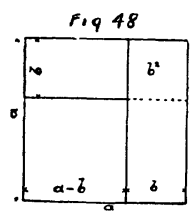

72. In the same way show that $(a-b)^{2}=a^{2}-$ $a b-a b+b^{2}=a^{2}-2 a b+b^{2}$.

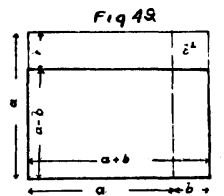

73. Similarly that $(a+b) \times(a-b)=a^{2}-b^{2}$.

74. From 68 make a rule for multiplying the sum of any two quantities by the sum of any other two quantities.

75. From 69 write a rule for multiplying differences.

76. What rule can you make from 70 and to what form of numbers will it apply?

77. Make a rule from your solution of $7 \mathrm{I}$; of 72 ; of 73 .

78. Test all the equations from 68 to 73 , calling $a=27, b=24, c=15, \mathrm{~d}=8$.

79. The two sides of the triangle in the figure are equal. If the area of the triangle is $t$, what is the area of the square on either short side? Denote the square on either short side by $a^{2}$. What equation can you write between $a^{2}$ and $t$ ? Between $a$ and $t$ ?

NotE. - The square root of $x$ is indicated thus $\sqrt{x}$ and read "square root of $x$."

8o. Calling the square on the long side $b^{2}$,

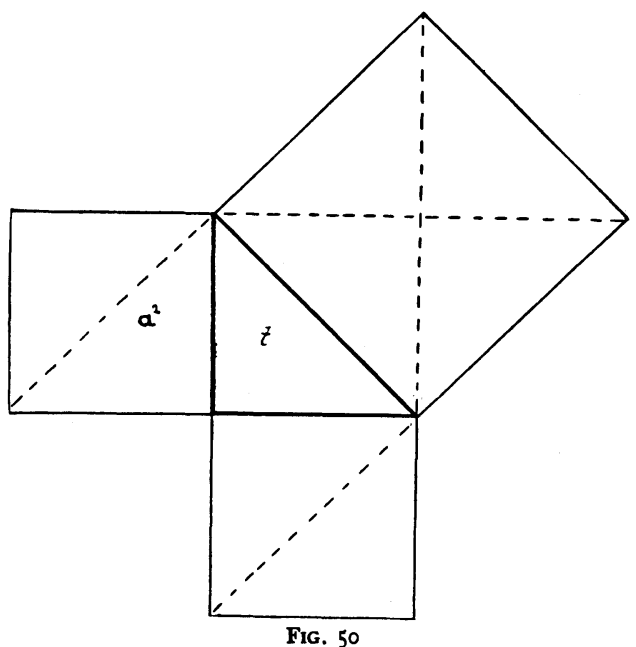

what equation can you write between $b^{2}$ and $t$ ? Between $b$ and $t$ ? From these two equations what third relation can you derive between $a^{2}$ and $b^{2}$ ? Between $a$ and $b$ ? What relation is there between the squares on the three sides?

8I. In the figure denote the sides of the right triangle by $a, b$, and $c$, and the areas of the various pieces by the letters which stand within them. Draw a figure such as the one indicated and cut along all dotted lines. See whether the pieces having the same letters will fit over

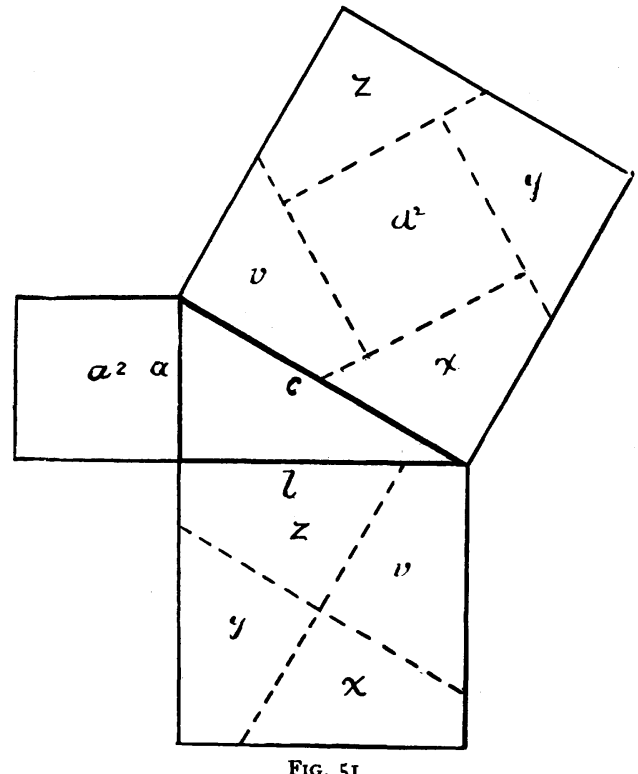

each other. Denoting the square on $a$ by $a^{2}$, on $b$ by $b^{2}$, and on $c$ by $c^{2}$, write an equation 
expressing $b^{2}$ in terms of the parts into which you have cut it; another equation for $a^{2}$ and another for $c^{2}$. Add the values of $a^{2}$ and $b^{2}$, member to member, and compare the sum with the value of $c^{2}$. What principle can you discover for the sides of this triangle? Compare this principle with the result of the last exercise. Perform this experiment with more than one right triangle. Does the principle hold for triangles not right angled?

This is one of the most important principles of geometry and should be thoroughly understood.

82. Draw very accurately a number of right angled triangles, measure their sides and test the principle of Ex. 8I.

Definition: The side opposite the right angle in a right angled triangle is called the hypothenuse.

It is known that the early Egyptians paved the floors of some of their buildings with isosceles right triangles. From this it has been suggested that the Egyptians knew this propo- sition for this special triangle. What do you think of the suggestion?

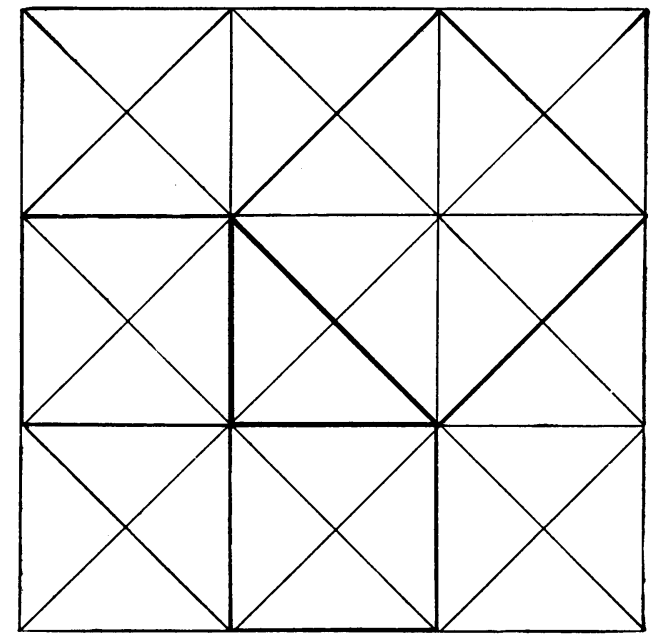

Fig. 52

\section{The High School}

Latin, Eighth and Ninth Grades: (AlLEN W. Gould.) Lessons XII, XIII, and XIV, printed in the January Course of Study, are simplified from Livy. The twelfth tells how the Roman matrons met by themselves and voted to give their ornaments to the treasury to pay a vow that had been made to Apollo. This story adds one more detail to the growing picture of the Roman matron. The pupils have seen her spinning and weaving the clothing of the family, and keeping her house with dignity and honor, as well as watching the omens and advising and encouraging her husband to do great deeds. Now the Roman matrons are seen to assemble by themselves and discuss the serious public matter of an unpaid debt to Apollo, and finally resolve that the debt shall be paid, and furnish the means for paying it.

The family life that made this high position of woman possible will seem perfectly natural to the students, because it is so much like our own modern home, and it may be necessary for them to see the position of the wife in Athens or in Asia at that time in order that they may appreciate the difference between the woman of the East and the woman of the West.

The maternal family as found among the American Indians, where the mother has to think and act almost wholly for herself and her children, can be described and contrasted with the Oriental family, where the wife is a cipher, and with the Roman and Anglo-Saxon family, where both husband and wife think and act. The pupils may then be asked which of these family types is the most helpful in making this world better. They may also be asked what danger there would be in the Roman family if both husband and wife thought for themselves. Would they be apt to think differently, and so divide the home? 